\title{
WABAH COVID-19 DAN JAMINAN PERLINDUNGAN ALLAH DALAM MAZMUR 23
}

\section{Desti Samarenna}

(Dosen STTI Harvest Semarang: destisamarenna@gmail.com)

\begin{abstract}
This article focuses on the COVID-19 information that has hit various countries in the world and results in high mortality rates. In Indonesia, various information emerged from social media that caused pressure, fear and even stress. This article is a literature review with a qualitative approach to the text of Psalm 23 about attitudes taken to deal with pressure or COVID-19. The purpose of writing

is to raise the theological significance of Psalm 23 and implement it into the life experiences of believers today, where everyone is in a plague situation. Psalm 23 is considered appropriate because it talks about three themes namely the exposition in this paper namely nurture (vv. 1-3), guarding (v. 4) and fellowship with God (vv. 5-6). The analysis is carried out by conducting a hermenetic study, which is combined with narrative analysis.
\end{abstract}

Keywords: Psalm 23, David, Shepherd, COVID-19.

\section{A. PENDAHULUAN}

COVID-19 (Coronavirus Disease 2019) pertama kali muncul di kota Wuhan, China dan menyebar ke manusia pada akhir Desember 2019. Virus Corona adalah sekumpulan virus dari subfamili Orthocoronavirinae dalam keluarga Coronaviridae dan Ordo Nidovirales. Kelompok virus ini menyebabkan terjadinya penyakit pada burung dan mamalia (termasuk manusia). ${ }^{1}$ Sebagian besar orang yang terinfeksi COVID-19 akan mengalami pernyakit pernafasan ringan hingga sedang dan sembuh tanpa memerlukan perawatan khusus. Orangorang yang telah lanjut usia serta mereka yang memiliki masalah medis mendasar seperti penyakit kardiovaskular, diabetes, penyakit pernafasan kronis, kanker dan sebagainya akan lebih mungkin mengembangkan penyakit serius ini. COVID-19 pada manusia dapat menyebabkan infeksi saluran pernafasan yang umumnya ringan tetapi sifatnya lebih mematikan. Virus Corona berkembang cepat dan telah menjalar dari Wuhan ke negara lainnya.

Ketakutan menjadi tema utama di era pandemi COVID-19, seperti ketakutan pada kesukaran ekonomi, penderitaan, bahaya, dan tersesat secara rohani karena gedung gereja ditutup. Ribuan orang bangun dengan beban tersembunyi yang tidak mampu dijelaskan, disertai dengan kecemasan yang harus dihadapi menanti berakhirnya COVID-19. Traumatik terhadap COVID-19 sebagai hal yang menakutkan dan harus dihindari. Rasa takut ini

${ }^{1}$ Andrew King, Elliot Lefkowitz, Michael J. Adams and Eric B. Carstens, Virus Taxonomy $1^{\text {st }}$ Edition: Ninth Report of the Internastional Committee on Taxonomy od Viruses (Oxfrod: Elsevier, 2011), 806. 
tentunya dianggap normal karena memang secara kenyataan, keadaan menjadi sulit dan angka kematian meningkat. Keadaan ini mengajarkan manusia untuk peduli lingkungan, yang tentunya berdampak pada kesehatan. Cara yang ditempuh antara lain: mencuci tangan, menggunakan masker dan menjaga suhu tubuh. Kebersihan diri dan kesehatan merupakan perwujudan nilai kemanusiaan untuk membantu menghentikan virus ini.

Kondisi tersebut di atas menggelisahkan dan membawa dampak serta respons yang berlebihan. Hal ini yang menyebabkan penulis untuk menuliskan artikel ini sebagai refleksi bagi orang percaya. Ada banyak situasi yang membuat manusia takut dalam menjalani kehidupan, salah satunya situasi pada saat pandemi ini. Takut adalah reaksi wajar manusia terhadap segala macam kesulitan dan bahaya, tetapi rasa takut itu seharusnya tidak ada dalam diri orang percaya. Namun demikian perspektif Kristiani mengajarkan bahwa orang Kristen tidak perlu mempunyai rasa takut pada situasi yang seperti ini. Firman Tuhan memberikan banyak dukungan untuk tetap mempercayai Tuhan sekalipun keadaan tidak menentu. Oleh sebab itu, seharusnya orang percaya dapat melawan ketakutan dengan iman kepada Tuhan, karena Tuhan telah berfirman, "Aku sekali-kali tidak akan membiarkan engkau dan Aku sekali-kali tidak akan meninggalkan engkau" (Ibr. 13:5).

Tujuan utama artikel ini adalah mengangkat makna teologis dari Mazmur 23 dan mengimplementasikannya ke dalam pengalaman hidup orang percaya di masa kini. Mazmur 23 dianggap tepat karena berbicara tentang tiga tema: pemeliharaan, penjagaan dan persekutuan dengan Tuhan. Analisis dilakukan dengan melakukan kajian hermeneutika yang digabung dengan analisis narasi. Hal itu diperlukan karena konten dari Mazmur 23 dipenuhi dengan bahasa metafora. Analisis dengan pendekatan literatur dilakukan untuk menyusun deskripsi atas pengungkapan tema pokok. Bagian terakhir dirasa perlu untuk menambahkan refleksi teologis dari Mazmur 23 agar diperoleh sikap rohani bagi orang Kristen yang tengah berada di tengah wabah COVID-19.

\section{B. METODOLOGI}

Metode yang digunakan dalam penelitian ini adalah metode penelitian kualitatif. Metode kualitatif ini digunakan dengan alasan karena masalah-masalah penelitian perlu digali untuk mendapatkan sebuah pengertian yang mendalam. ${ }^{2}$ Teknik pengumpulan data kualitatif dilakukan dengan menggunakan sumber data primer melalui kajian buku-buku literatur, tafsir

\footnotetext{
${ }^{2}$ John W. Creswell, Educational Research (Boston: Pearson, 2012), 8-16.
} 
dan eksposisi untuk mendapatkan informasi yang mendalam. ${ }^{3}$ Tahap selanjutnya adalah menyusun data yang telah dikumpulkan melalui buku-buku, memilih yang penting untuk dideskripsikan, dan disimpulkan.

\section{PEMBAHASAN}

Kitab Mazmur sebagian besar bersifat pribadi yang memiliki kesan penggambaran Allah secara pribadi yang terlibat langsung dalam dunia. Tuhan digambarkan menurut situasi kehidupan sehari-hari, sebagai seorang gembala yang memperhatikan domba-dombanya. ${ }^{4}$ Berbagai judul dari mazmur sering mencantumkan kata depan Ibrani: lamedh ("dari, untuk, atau bagi") di depan nama orang-orang yang penting. Tidak dapat dipastikan berapa dari tujuh puluh tiga mazmur yang dalam judulnya mencantumkan nama Daud di depan preposisi lamedh yang benar-benar ciptaannya sendiri meski banyak dari mazmur adalah ciptaan Daud karena aktivitas dan kemampuan Daud dalam bidang musik sehingga sulit membantah peranannya dalam penulisan mazmur. ${ }^{5}$

Mazmur 22-31 adalah satu mazmur pujian. ${ }^{6}$ Mazmur 23 ditulis oleh Daud dan digolongkan ke dalam Mazmur nyanyian ekspresi iman, penyerahan, sukacita dalam hadirat Allah. Daud mengekspresikan ucapan syukur dan pemeliharaan Tuhan di dalam dan sepanjang hidupnya. Gagasan utamanya adalah nyanyian yang mengungkapkan kepercayaan Daud yang menghalau dukacita, kesedihan, dan keraguan. Damai sejahtera, kepuasan, dan kepercayaan telah menjadi berkat dan dasar keyakinan pemazmur. ${ }^{7}$ Kitab ini digunakan sebagai bahan pengajaran untuk beribadah kepada Tuhan, yaitu pemberian tanggapan yang wajar atas keberadaan, firman dan perbuatan-perbuatanNya.

Mazmur 23:1-6 mengandung tiga jaminan perlindungan Tuhan kepada orang percaya dalam menghadapi COVID-19, yaitu: pemeliharaan Tuhan (ay. 1-3), perlindungan Tuhan (ay. 4) dan persekutuan dengan Tuhan (ay. 5-6).

${ }^{3}$ Gidion Gidion, "Memahami Pekerjaan Roh Kudus Dalam Pelayanan Gereja Berdasarkan 1 Dan 2 Timotius," HARVESTER: Jurnal Teologi dan Kepemimpinan Kristen 4, no. 2 (2019): 108-121, http://ejournal.sttharvestsemarang.ac.id/index.php/harvester/article/view/14.

${ }^{4}$ Bullock, Kitab-kitab Puisi dalam perjanjian Lama, 181.

${ }^{5}$ Bullock, 160.

${ }^{6}$ Andrew E. Hill \& John H. Walton, "Kitab Mazmur", dalam Survei Perjanjian Lama (Malang: Gandum Mas, 2004), 449.

${ }^{7}$ Kyle M. Yates, "Mazmur" dalam Tafsiran Alkitab Wycliffe: Perjanjian Lama AyubMaleakhi, Vol.2, Peny Charles F. Pfeiffer (Malang: Gandum Mas, 2005), 143. 


\section{Pemeliharaan Tuhan (Ay. 1-3)}

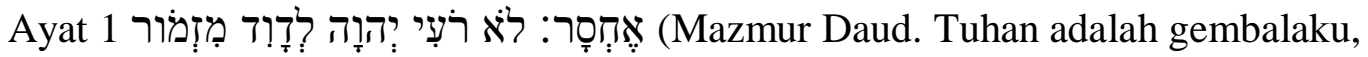
takkan kekurangan aku). Nama "Daud" dalam bahasa Ibrani: Dawid. Daud adalah anak Isai dari suku Yehuda yang bekerja sebagai penggembala domba. Daud belajar kelemahlembutan dan pengasuhan saat mengembalakan kawanan dombanya yang kemudian disyairkan sebagai sifat-sifat Allahnya. ${ }^{8}$ Daud menjadi bapa leluhur dari Yesus seperti tertera dalam Injil (Mat. 1:1-17). Daud adalah raja yang menggantikan Saul. Beberapa ahli berpendapat bahwa Daud ketika masih muda menggembalakan kambing domba milik ayahnya (1Sam. 16:11) yang kemudian melukiskan hubungan antara Tuhan dengan orang yang diurapiNya. ${ }^{9}$ Penafsir yang lain menjelaskan penulisan mazmur ini sehubungan dengan pemberontakan Absalom terhadap Daud (2Sam. 15-17). ${ }^{10}$ Kalau melihat dalam konteks kitab Kejadian 49:24; 48:15, Tuhan bertindak sebagai gembala yang menuntun umatNya. Gembala kambing dan domba di Israel memegang peranan penting baik dalam hidup peribadahan maupun dalam perekonomian secara nasional. Domba di Palestina bersandar sepenuhnya pada perlindungan dari gembala yang menyelamatkannya dari ancaman singa dan beruang (1Sam. 17:34-35; Ams. 3:12), yang memeriksa jumlah mereka (Yer. 33:13), dan yang pergi mencarinya bila ada yang kurang (Mat. 18:11). ${ }^{11}$

“Tuhan adalah gembalaku”, רעצי: יהוָה (Yehovah Ro'i) dituliskan dalam bentuk metafora. Struktur dalam metafora memiliki dimensi inkarnasi, penyampaian bahasa yang akomodatif dari Allah sang pencipta kepada mahluk ciptaan, yang merendahkan diriNya berbicara dalam bahasa manusia. Firman Tuhan, dengan menggunakan metafora gembala tetapi memberikan arah pemahaman imajinasi terhadap manusia yang berdosa. ${ }^{12} \mathrm{Kata}$ "ku," menunjukkan kepemilikan, bahwa secara pribadi Allah memelihara dan menggembalakan atau memperhatikan satu-satu setiap orang yang percaya. Daud memberikan penjelasan bahwa Allah sebagai seorang gembala yang baik dan Allah mengendalikan seluruh hidupnya.

${ }^{8}$ T.H Jones, "Daud" dalam Ensiklopedi Alkitab Masa Kini, Jil.1 A-L, pen., M.H. Simangkalit (Jakarta: Yayasan Bina Kasih/OMF, 2002), 238.

${ }^{9}$ Marie C. Barth dan B.A. Pareira, Tafsiran Alkitab Kitab Mazmur 1-72 (Jakarta: BPK Gunung Mulia, 1999), 291.

${ }^{10}$ Ian Barcklay, Bagiku, Dialah segalaNya (Ulasan Mazmur 23) (Jakarta: BPK Gunung Mulia, 1987), 7.

${ }^{11}$ W.R.F. Browning, "Gembala", dalam Kamus Alkitab (Jakarta: BPK Gunung Mulia, 2007), 116-117.

${ }^{12}$ Billy Kristanto, Ajarlah kami bergumul (Surabaya: Momentum, 2010), 99. 
Daud sepenuhnya bergantung kepada Tuhan seperti domba pada gembala. Kata "domba," adalah kata yang dipakai oleh pemazmur untuk menjelaskan hubungan pribadi dengan gembala. ${ }^{13}$ Kata-kata ini dilatarbelakangi oleh pengalaman panjang mempercayai Allah. ${ }^{14}$ Dalam Yohanes 10:3b dijelaskan bahwa "Ia memanggil domba-dombanya masingmasing menurut namanya dan menuntunnya keluar". Gembala mengenal dombanya dan demikian sebaliknya. Tugas seorang gembala sangat penting, yaitu mencukupi kebutuhan domba dan berjaga-jaga dari ancaman musuh.

Kata (lo 'ekhsar) adalah kata kerja imperpek orang pertama tunggal, yang artinya "tidak kekurangan". Hal itu secara konteks bermakna gembala akan menyediakan segala yang diperlukan. Ciri khas dari metafora yang panjang ini adalah penyediaan Tuhan atas apa yang diperlukan bahwa Tuhan adalah Jehovah Jireh, artinya Tuhan yang melihat dan menyediakan. Orang percaya harus berfokus kepada Allah sebagai gembala yang baik dan setia yang akan terus menerus membimbing dan memelihara umatNya.

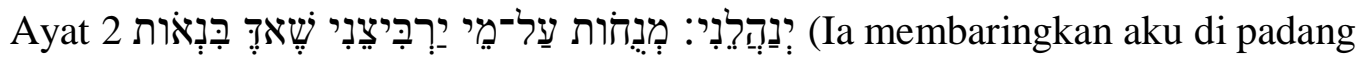
yang berumput hijau, Ia membimbing aku ke air yang tenang;). Terlihat ada paralel di dalam kalimat "Ia membaringkan" dan "Ia membimbing". Keduanya menjelaskan fungsi mengarahkan. Daud memberikan metafora bahwa pengarahan Tuhan dalam hidupnya

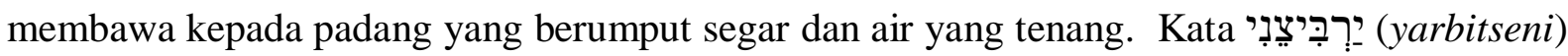
"Ia membaringkan" adalah kata kerja hipil imperpek yang menjelaskan tentang ketentraman berbaring dengan beristirahat (terlentang). Ketenangan ini dijelaskan sebagai Jehovah Shalom, artinya Tuhan yang memberi damai.

"Rumput" dan "air" merupakan kebutuhan dari domba dan pasti diberikan oleh gembalanya. "Padang rumput" adalah penjelasan dari pemeliharaan Tuhan atas umatNya. “Air” melambangkan kehidupan dan ketenangan menghadapi persoalan, kesulitan dan gelombang. Tuhan berjanji memberikan semua yang dibutuhkan (Mat. 6:25-34). Daud merasakan pemberian Tuhan adalah sebuah padang penggembalaan terbaik yang mana terdapat rumput segar. Ayat tersebut menjelaskan bahwa ada standar kualitas pemeliharaan, yaitu kenyamanan.

${ }^{13}$ Leslie S M'Caw \& J. A. Motyer, "Mazmur", dalam Tafsiran Alkitab Masa Kini 2: Ayub-Maleakhi, pen., F. Ukur (Jakarta: Yayasan Komunikasi Bina Kasih/OMF), 151.

${ }^{14}$ Yates, "Mazmur", dalam Tafsiran Alkitab Wycliffe: Perjanjian Lama AyubMaleakhi, 143. 


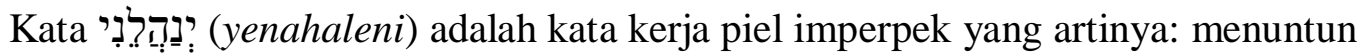
beristirahat dan menyegarkan. Domba takkan kekurangan bukan karena melihat rumput dan air, tetapi karena adanya gembala, yaitu Tuhan sebagai sumber penyedianya. Setiap orang percaya pasti memiliki persoalan bagaimana melanjutkan hidup dan bertahan ketika harus tinggal di rumah. Ada banyak masalah yang tidak bisa dihindari, tetapi Daud mengajak melihat ke dalam teks dan menegaskan bahwa Tuhan yang menjadi gembala tidak pernah membawanya ke air yang bergolak, melainkan ke air yang tenang. Domba bergantung kepada gembala untuk menemukan padang rumput dan air.

Gembala adalah yang bertanggungjawab menyediakan perlindungan dan segala kebutuhan dombanya. Domba hampir tidak berdaya tanpa gembala. Demikian juga dengan Tuhan yang memberikan kehidupan dan pemeliharaan sesuai dengan berkat yang dipercayakan. Kehidupan yang teduh bukan berarti tidak ada masalah dan pergumulan, tetapi soal ketenangan menghadapi persoalan dan kesulitan. Percaya pada pemeliharaan Tuhan membuat orang percaya mampu melewati situasi yang sulit. Pencobaan boleh ada, tetapi orang percaya tetap hidup dengan tenang.

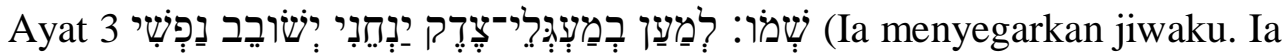
menuntun aku dijalan yang benar oleh karena namaNya). "Ia menyegarkan jiwaku" dalam New International Version (NIV): "He restores my soul”, artinya Ia memulihkan jiwaku. Kata “menyegarkan” jika diterjemahkan "memulihkan” berarti memulihkan dari kelelahan. Menyegarkan jiwa bukanlah soal lahiriah, tetapi soal kemampuan untuk melewati tekanan. Frasa "Ia menuntun aku di jalan yang benar oleh karena namaNya" menunjukkan ukuran dalam jalan adalah "jalan yang benar". Jehovah Tsid'kenu adalah salah satu gelar Allah yang berarti Tuhan adalah kebenaran kami.

Perjanjian Lama menjelaskan bahwa kebenaran Allah adalah hal yang layak dipercaya (Yes. 65:16). ${ }^{15}$ Jalan kebenaran didasarkan pada firman, Keluaran 18:20, “...memberitahukan jalan yang harus dijalani”. Dalam 1 Samuel 12:23, “Aku mengajarkan kepada kamu jalan yang baik" dan 2 Samuel 22:22, "aku akan mengikuti jalan Tuhan”. ${ }^{16}$ Jika melihat pengalaman Daud ketika di tengah kesulitan hidup, saat terjepit dihadang musuh dan dalam pelarian, Daud tidak meninggalkan Tuhan. Daud justru mencari kehendak Tuhan. Teks menjelaskan bahwa Tuhan yang memimpin dalam segala situasi.

\footnotetext{
${ }^{15}$ Browing, "Kebenaran", dalam Kamus Alkitab, 55.

${ }^{16}$ D. F. Walker, "Jalan”, dalam Konkordansi Alkitab (Jakarta: BPK Gunung Mulia, 2002), 198.
} 
Nama Tuhan menjadi penting karena sebagai tanda mengenaliNya sekaligus tanda seruan kepadaNya. Tuhan membimbing secara pribadi oleh karena namaNya dan bukan karena diri orang percaya. Tuhan memberikan satu tempat untuk memulihkan kembali dan mengarahkan jalan hidup yang mungkin menyimpang dari firman Tuhan. Pemeliharaan Tuhan dalam ayat 1-3 berkaitan dengan pemeliharaan hidup.

\section{Perlindungan Tuhan (Ay. 4)}

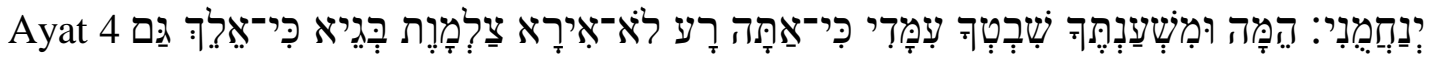
(Sekalipun aku berjalan dalam lembah kekelaman, aku tidak takut bahaya, sebab Engkau besertaku; gadaMu dan tongkatMu, itulah yang menghibur aku). Daud diperhadapkan pada situasi dan kondisi yang mana satu-satunya pilihan adalah berhadapan dengan situasi tersebut. Orang lain bisa menghindar, tetapi Daud tidak punya pilihan. Kata כִּי־ (ki-'elekh) adalah kata kerja imperfek orang pertama tunggal yang menjelaskan bahwa Daud pergi atau berjalan ke lembah di Moab. Frasa "lembah kekelaman" dalam King James Version (KJV), Revised Standard Version (RSV) dan NIV tertulis: valley of the shadow of death, yang diterjemahkan

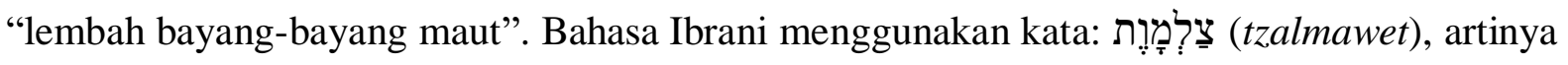
tangisan, bayangan gelap, kesusahan, bahaya ekstrim dan ciri dunia orang mati. ${ }^{17}$ Kata tersebut juga berarti hal yang tidak menyenangkan dan menakutkan.

Lembah kelam dalam teks ini adalah tempat yang berkelok-kelok tanpa dapat melihat apa yang terjadi atau siapa yang akan menghadang di tikungan berikutnya. "Lembah kekelaman" adalah terjemahan dari En-Gedi. Beberapa kali Daud harus melewati wilayah EnGedi ini, yaitu pada saat Daud dikejar-kejar oleh Saul dan juga pada waktu menghindar dari kejaran Absalom, anaknya sendiri. Ini adalah pengalaman pribadi yang menantang bahaya, berada dalam persoalan-persoalan, penuh dengan risiko dan musuh bisa saja datang tiba-tiba.

Daud beberapa kali ditempatkan dalam situasi tersebut, tetapi Daud tidak takut. Ada keyakinan yang kuat dalam dirinya bahwa Allah tidak pernah meninggalkannya. Itu sebabnya Daud berkata, "Aku tidak takut bahaya, sebab Engkau besertaku”. Ini adalah kiasan untuk bahaya yang ditimbulkan musuh-musuh Daud. Secara etimologi dan pemakaian kata, kata itu lebih mungkin merupakan kata benda abstrak yang artinya "kekelaman pekat"18 Kata itu sering dikaitkan untuk kegelapan dalam teks-teks puisi. Kegelapan dalam beberapa contoh

\footnotetext{
${ }^{17}$ Bible work 6

${ }^{18}$ Roy B. Zuck, “Mazmur”, dalam A Biblical Theology of The Old Testament, pen.,
} Suhadi Yeremia (Malang: Gandum Mas, 1991), 514-515. 
digambarkan berkaitan dengan dunia orang mati (Ayb. 10:21-22; 38:17), tetapi nuansa ini diperoleh dari konteks dan tidak melekat kepada arti kata itu sendiri.

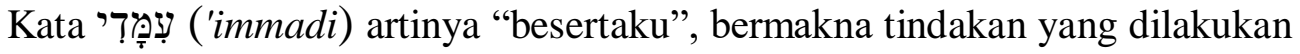
bersama-sama. Jehovah 'Im 'kha memiliki pengertian Tuhan menyertai engkau. Daud kemudian memberikan penjelasan bahwa Allah yang ada bersama-sama dengan dia memiliki gada (senjata yang digunakan dalam pertempuran satu lawan satu dalam jarak pendek) dan tongkat (otoritas) yang berada di tanganNya. Tongkat itu adalah tongkat yang dikenakan dipinggang dan merupakan alat tradisional dari gembala. ${ }^{19}$

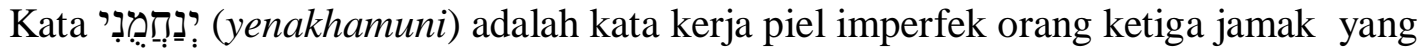
artinya "kenyamanan". Kekuatan Daud terletak pada keyakinan akan kenyamanan yang Tuhan berikan, meski dalam situasi yang tidak mampu dipahami. Setiap orang percaya seharusnya membangun keyakinan kepada Allah, tidak saja dalam situasi yang baik tetapi juga dalam situasi yang buruk. Serangan kemalangan hidup dalam bayang-bayang maut muncul dalam bentuk sakit penyakit, kematian dan penderitaan. ${ }^{20}$ Kepercayaan kepada Tuhan menjadi teguh sekalipun berada pada situasi yang tak terjelaskan, karena Tuhan memberikan jaminan diriNya sendiri, gada dan tongkat yang melindungi.

Tuhan adalah perisai pertolongan (Jehovah Magen'ezrekha). Informasi yang didengarkan setiap hari oleh media mengenai COVID-19 justru mengikis kepercayaan kepada Tuhan. Orang percaya mulai terintimidasi dengan dunia dan lebih percaya pendapat dunia dari pada jaminan dalam firmanNya. Penjelasan teks tidak mengarah kepada kematian, tetapi kesulitan dan tantangan yang dihadapi. Teks Alkitab memberikan jaminan rasa aman itu, bahkan ketika berjalan dalam bayang-bayang maut.

\section{Persekutuan dengan Tuhan (Ay. 5-6)}

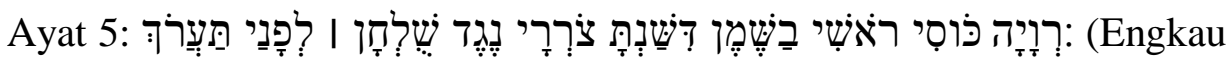
menyediakan hidangan bagiku, dihadapan lawan-lawanku; Engkau mengurapi kepalaku dengan minyak; pialaku penuh melimpah). Metafora yang dipakai dalam ayat 5 ini adalah tuan rumah dan tamu. Tradisi pada saat itu mengharuskan tuan rumah untuk bersikap ramah terhadap tamu. Daud memberikan penegasan bahwa dihadapan lawanpun, apa yang menjadi

${ }^{19}$ John H. Walton, Victor H. Matthews \& Mark W. Chavalas, "Psalm”, dalam The IVP Bible Backgroud Commentary Old Testament (USA: Zondervan Publishing House, 2000), 524.

${ }^{20}$ M'Caw \& J.A Motyer, "Mazmur”, dalam Tafsiran Alkitab Masa Kini 2: AyubMaleakhi, 151. 
kebutuhannya disediakan oleh Tuhan. Dalam bahasa Inggris, kata "lawan" ada dalam bentuk jamak: enemies, berarti musuh-musuh. Teks menjelaskan bahwa domba ternyata banyak musuhnya.

Frasa "Engkau menyediakan hidangan bagiku" menjelaskan bahwa Allah adalah seorang gembala yang akan menyediakan bagi Daud, seperti yang dilakukan gembala untuk kawanan dombanya. Teks memberikan buktinya: Allah telah menyediakan meja (pesta) dan telah mengisi cawannya dengan sukacita. Ini adalah penjelasan periode tertentu dari kehidupan pemazmur. Tuhan tiba-tiba menyediakan kebutuhannya ketika Daud dalam kekurangan dan kekuatiran akan binasa.

Frasa "dihadapan musuhku" bermakna terlepas dari para musuh atau para musuh tidak dapat mencegahnya. Konteks orang percaya saat ini adalah akan ada banyak orang yang memusuhi dan menentang karena menaati Tuhan. Kisah Para Rasul 24:5 berkata, "Telah nyata kepada kami, bahwa orang ini adalah penyakit sampar, seorang yang menimbulkan kekacauan di antara semua orang Yahudi di seluruh dunia yang beradab, dan bahwa ia adalah seorang tokoh dari sekte Nasrani”. Teks ini menjelaskan Paulus yang sekalipun saleh, tetapi mengalami banyak permusuhan dan pertentangan. Paulus bahkan disebut "penyakit sampar", yang dalam Bahasa Yunani memakai kata loimon, yang berarti penyakit sampar, wabah, atau gangguan. Paulus justru tidak melakukan gangguan, melainkan memberitakan Injil. Justru orang-orang yang menolak pemberitaannya itu yang membuat kekacauan. Ada banyak hal yang menakutkan, tetapi teks menjelaskan bahwa Tuhan menyertai dan melindungi. Tuhan memberkati ditengah-tengah musuh atau kesukaran hidup.

"Engkau mengurapi kepalaku dengan minyak" dalam Bahasa Ibrani diterjemahkan dengan "membuat lemak". Ini adalah ekspresi kelimpahan. Daud memposisikan diri sebagai orang yang dipilih Tuhan. Pengurapan di zaman Daud berbicara tentang orang yang terpilih, yang kepadanya Allah berkenan memberikan pesan tertentu. berada dalam perlindungan Allah dan dipuaskan secara penuh. ${ }^{21}$ Frasa itu mengindikasikan kemakmuran dan sukacita ilahi. "Pialaku penuh melimpah" bermakna pemenuhan secara berkelimpahan, terutama secara fisik. Allah digambarkan sebagai tuan rumah yang menjamu tamuNya. Piala biasa digunakan untuk menampung sesuatu. Daud menjelaskan tentang kesaksiannya dihadapan musuhmusuhnya, bagaimana ia menjadi satu pribadi yang hidupnya berada dalam kemurahan Allah sepanjang waktu. Kemurahan itu menyebabkan Daud tidak saja mendapat sesuatu yang

${ }^{21}$ Yates, "Mazmur", dalam Tafsiran Alkitab Wycliffe: Perjanjian Lama AyubMaleakhi, 144. 
cukup, tetapi melimpah. Kehidupan Daud dan orang yang percaya menjadi kesaksian dihadapan kawan dan lawan sebagai orang pilihan melalui pemenuhan itu.

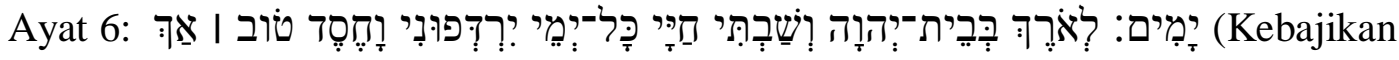
dan kemurahan belaka akan mengikuti aku, seumur hidupku; dan aku akan diam dalam Rumah Tuhan sepanjang masa). Daud memberikan tesis atas apa yang dikemukakan di ayat pertama, sebagai akibat dari Tuhan yang menjadi gembalanya, yaitu kebajikan dan kemurahan

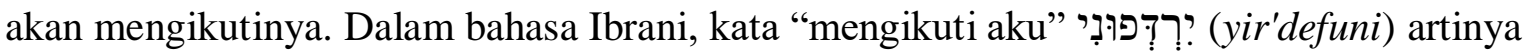
mengejar aku. Ungkapan ini menandakan kehebatan dan kesiapan Allah untuk berbuat baik kepada umatNya, dengan berkat-berkatNya yang mengejar.

Efek dari tindakan belas kasihan Allah kepada Daud adalah mengarahkan kepastian bahwa Allah akan selalu menjadi gembala yang tidak pernah meninggalkan. Pengalaman tentang kebaikan dan belas kasihanNya memberikan jaminan bahwa akan terus berlanjut sampai akhir. Setiap orang yang menjadikan Tuhan sebagai gembalanya, maka akan dikejar oleh kebajikan dan kemurahan. Teks ini adalah perenungan Daud yang telah menjalani yang baik, jahat dan yang buruk. ${ }^{22}$ Dalam KJV dituliskan, "hanya kebaikan dan kemurahan akan mengikuti aku seumur hidupku, walaupun beberapa dari hari-hari tersebut membawa Daud melalui lembah bayangan kematian.

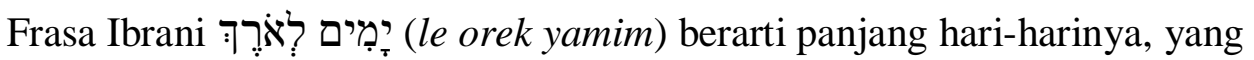
menerangkan periode waktu. Ungkapan "seumur hidupku” menjelaskan tentang semua hari dalam hidup Daud. Melalui semua perubahan dalam segala keadaan sampai mencapai akhir hidupnya. Hidup memang akan berakhir, namun Daud tidak menjelaskan kapan itu terjadi. Ini adalah ungkapan hati yang dipenuhi dengan sukacita dan terima kasih atas perenungan masa lalu dan penuh dengan harapan sehubungan dengan masa depan.

KJV menggunakan kata "I will dwell”, mengasumsikan bahwa kata tersebut adalah bentuk dari kata kerja yāša menggunakan kata wayāšabtiy, yang membuatnya menjadi bentuk kata kerja yāša "tinggal”.

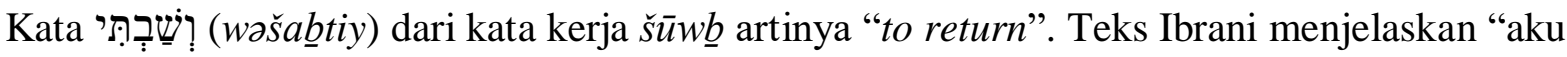
akan kembali (I will return) ke rumah Tuhan”. Mengingat betapa miripnya kedua kata itu, tidak sulit untuk melihat bagaimana penyalin selanjutnya keliru menyalin יותי sebagai ושתי, dan ejaan yang keliru ini kemudian dipertahankan dalam Teks Masoret. Konteksnya adalah

${ }^{22}$ Dutch Sheets \& Chris Jackson, Doa untuk Mengatasi Masa Sukar (Light Publishing, 2008), 182. 
Daud akan kembali ke rumah Tuhan dan beribadah kembali di Bait Suci. ${ }^{23}$ Ini adalah kerinduan Daud.

Rumah Tuhan pada waktu itu adalah Bait Suci. Ungkapan "dan aku akan diam dalam Rumah Tuhan sepanjang masa" dalam bahasa Ibrani berarti "panjang hari”. Teks ini tidak merujuk pada keabadian atau surga, tetapi sejajar dengan ungkapan sebelumnya "sepanjang hidupku", yaitu Daud akan kembali tinggal di Rumah Tuhan selama Daud hidup. Ungkapan itu beberapa kali digunakan dalam mazmur sebagai indikasi keinginan pemazmur. Orang yang disertai Tuhan akan memperoleh hal-hal yang baik dan berhadapan dengan kemurahan. Kerinduan Daud terungkap dalam perikop ini, bahwa Tuhan menjadi segala-galanya dalam hidupnya. Ini adalah ekspresi kerinduan jiwa untuk merasakan kehadiran Allah yang terus menerus, dan perwujudan persekutuan yang terus menerus dengan Tuhan. 2 Timotius 2:13 berkata, "Jika kita tidak setia, Dia tetap setia, karena Ia tidak dapat menyangkal diriNya".

\section{Refleksi Teologis Mazmur 23}

Menghadapi wabah COVID-19 tentunya memunculkan kekuatiran dan kegelisahan akan kapan berakhirnya pandemi tersebut. Dampak dari wabah ini tidak hanya dalam bidang ekonomi saja, tetapi menyentuh bagian yang pribadi yaitu tertutupnya kesempatan beribadah bersama. Kematian juga menjadi ciri utama dari situasi ini, tidak memandang jabatan dan status. Situasi ini menimbulkan rentetan pertanyaan: "Mengapa ini bisa terjadi? Kalau benarbenar Allah ada, kalau Allah Mahakasih, bagaimana Ia dapat membiarkan tragedi ini? Allah macam apa yang diam saja, yang tidak melakukan apa-apa? Dimanakah Allah ketika peristiwa ini terjadi? ${ }^{24}$ Itu menjadi pertanyaan yang penting ketika situasi ini terjadi.

Mazmur 23 secara konteks bukan berbicara tentang penghiburan setelah kematian, meskipun ayat 4 dan 6 kadang secara khusus dipahami seperti itu. Ayat 4 mengacu kepada gembala yang menuntun dombanya (pemazmur) melewati lembah kelam yang berbahaya. Mazmur 23 menyatakan tiga bentuk perlindungan Tuhan dalam menghadapi wabah COVID19: Pertama, mempercayai pemeliharaan Tuhan. Tesis dari Mazmur 23 ini adalah Yehovah $R o$ ' $i$ artinya “Tuhan adalah gembalaku”. Keyakinan ini berlaku bagi siapa saja yang percaya

\footnotetext{
${ }^{23}$ Walton, Matthews \& Chavalas, "Psalm" dalam The IVP Bible Backgroud Commentary Old Testament, 525.

${ }^{24}$ Luis Palau, Di Manakah Allah Kala Peristiwa Buruk Terjadi, pen., Doreen Widjana (Bandung: Lembaga Literatur Baptis, 2001), 10.
} 
kepada Tuhan. Ada jaminan yang Tuhan berikan, yaitu takkan kekurangan. Situasi dan keadaan bolehlah sulit tetapi Tuhan akan menolong dan memberikan jalan keluar.

Tuhan sebagai gembala yang "membaringkan" dan "membimbing” menyatakan adanya kenyamanan dan ketenangan meski keadaan dan situasi tidak menentu. Tuhan akan membimbing, tetapi bukan berarti orang percaya tidak mengikuti aturan dan ketetapan yang telah dilakukan oleh pemerintah. Teks menjelaskan bahwa Tuhan akan "menyegarkan" meski di tengah kelelahan dan kegersangan jiwa. Jiwa yang letih dan tidak bergairah menghasilkan kinerja yang buruk dan daya tahan tubuh yang rendah, karena itu janji penyegaran jiwa diberikan oleh Tuhan. "Ia menuntun aku dijalan yang benar oleh karena namaNya" merupakan jaminan untuk terus berjalan menghadapi tantangan zaman. Kedua, mempercayai perlindungan Tuhan. Perlindungan Tuhan nyata sekalipun ada banyak kesulitan, ketegangan, bahkan akhir yang tak berujung dalam situasi yang sulit. Tuhan meneguhkan bahwa orang yang percaya senantiasa ada dalam penjagaan Tuhan. Itulah penghiburan, bahwa ada perlindungan Tuhan meski dalam situasi pandemi yang tidak diketahui kapan berakhirnya.

Ketiga, memiliki persekutuan dengan Tuhan. Tuhan menjanjikan pemeliharaan dan kelimpahan dalam situasi yang dihadapi. Orang yang percaya kepada Tuhan akan dikejar oleh kebaikan dan kemurahan seumur hidupnya. Alkitab menyodorkan janji dalam persekutuan dengan Tuhan yaitu dapat memiliki hatiNya serta pandanganNya, prioritas-prioritasNya, target dan tujuanNya saat ini dan Alkitab mengundang berjalan bersama Allah saat ini. ${ }^{25}$ Tidak ada bagian atau celah untuk Tuhan tidak menyertai. Jaminan itu berlaku bagi orang yang mencari Tuhan dan menikmati persekutuan dan hubungan yang indah dalam hadiratNya. Mazmur 23 mengajak setiap orang untuk mempercayai Tuhan sebagai gembala yang baik dan menyakini perlindungan Tuhan dari para musuh. Tuhan pasti melindungi milik kepunyaanNya dan keyakinan kepada Allah pasti membenarkan orang benar yang memiliki persekutuan dengan Tuhan sampai akhir hidupnya.

\section{KESIMPULAN}

Wabah COVID-19 dan perlindungan Tuhan dalam Mazmur 23:1-6 mengajarkan tiga bentuk perlindungan dalam teks. Ada nama-nama Allah yang dahsyat diperkenalkan dalam Mazmur 23: Tuhan adalah gembalaku (Yehovah Ro'i) yang memberikan jaminan

${ }^{25}$ Dennis F. Kinlaw, The Mind of Christ: Mendalami Cara Berfikir Allah untuk Menjalani Hidup yang Penuh Makna, peny., Natan S. Gultom, pen., Perwira Leo Sabath (Yogyakarta: Yayasan ANDI, 2009), 36. 
pemeliharaan, Tuhan yang melihat dan menyediakan (Jehovah Jireh), Tuhan yang memberi damai (Jehovah Shalom), Tuhan kebenaran kami (Jehovah Tsid'kenu) dan Tuhan adalah perisai pertolongan (Jehovah Magen'ezrekha). Jaminan perlindungan Tuhan bahkan dalam situasi yang sulit dan tidak menentu. Persekutuan dengan Tuhan membuat orang yang percaya dikejar oleh kebajikan dan kemurahan Tuhan seumur hidup. Pemahaman yang benar tentang Tuhan ditunjukkan dalam sikap hidup, yaitu percaya kepada pemeliharaan, perlindungan serta persekutuan dengan Tuhan. 


\section{DAFTAR PUSTAKA}

Barcklay, Ian. Bagiku, Dialah segalaNya (Ulasan Mazmur 23). Jakarta: BPK Gunung Mulia, 1987.

Barth, Marie C. dan B.A. Pareira. Tafsiran Alkitab Kitab Mazmur 1-72. Jakarta: BPK Gunung Mulia, 1999.

Browning, W.R.F. “Gembala.” Dalam Kamus Alkitab. Jakarta: BPK Gunung Mulia, 2007.

Bullok, C. Hassel. Kitab-kitab Puisi dalam Perjanjian Lama. Malang: Gandum Mas, 2003.

Creswell, John W. Educational Research. Boston: Pearson, 2012.

Gidion, Gidion. "Memahami Pekerjaan Roh Kudus dalam Pelayanan Gereja Berdasarkan 1 dan 2 Timotius." HARVESTER: Jurnal Teologi dan Kepemimpinan Kristen 4.2 (2019): $108-121$.

Hill, Andrew E. \& John H. Walton. "Kitab Mazmur.” Dalam Survei Perjanjian Lama. Malang: Gandum Mas, 2004.

Jones, T.H "Daud.” Dalam Ensiklopedi Alkitab Masa Kini. Jilid 1 A-L. Penerjemah M.H. Simanugkalit. Jakarta: Yayasan Bina Kasih/OMF, 2002.

King, Andrew. Elliot Lefkowitz. Michael J. Adams and Eric B. Carstens. Virus Taxonomy $1^{\text {st }}$ Edition: Ninth Report of the Internastional Committee on Taxonomy od Viruses. Oxfrod: Elsevier, 2011.

Kinlaw, Dennis F. The Mind of Christ: Mendalami Cara Berfikir Allah untuk Menjalani Hidup yang Penuh Makna. Penyunting Natan S. Gultom. Penerjemah Perwira Leo Sabath. Yogyakarta: Yayasan ANDI, 2009.

Knopf, “Jeffrey W. Doing a Literatur Review,” PS-Politic Science and Politics, 2006.

Kristanto, Billy. Ajarlah kami bergumul. Surabaya: Momentum, 2010.

M'Caw, Leslie S \& J.A Motyer. "Mazmur." Dalam Tafsiran Alkitab Masa Kini 2: AyubMaleakhi. Penerjemah F. Ukur. Jakarta: Yayasan Komunikasi Bina Kasih/OMF.

Palau, Luis. Di Manakah Allah Kala Peristiwa Buruk Terjadi. Penerjemah Doreen Widjana. Bandung: Lembaga Literatur Baptis, 2001.

Sheets, Dutch \& Chris Jackson. Doa untuk Mengatasi Masa Sukar. Light Publishing, 2008.

Strong, James. "Mizmor." in A Concise Dictionary of the words in The Hebrew Bible The complete Word Study Old Testament. Penyunting Spiros Zodhiates. Chattanooga: AMG Publisher, 1992.

Walker, D.F. “Jalan.” Dalam Konkordansi Alkitab. Jakarta: BPK Gunung Mulia, 2002. 
Walton, John H, Victor H. Matthews \& Mark W. Chavalas. "Psalm." Dalam The IVP Bible Backgroud Commentary Old Testament. USA: Zondervan Publishing House, 2000.

Yates, Kyle M. “Mazmur.” Dalam Tafsiran Alkitab Wycliffe: Perjanjian Lama Ayub-

Maleakhi. Volume 2. Penyunting Charles F. Pfeiffer. Malang: Gandum Mas, 2005.

Zuck, Roy B. "Mazmur.” Dalam A Biblical Theology of The Old Testament. Penerjemah Suhadi Yeremia. Malang: Gandum Mas, 1991.

Sumber Elektronik:

https://www.merriam-webster.com/dictionary/corona diakses 5 Mei 2020.

https://www.who.int/health-topics/coronavirus\#tab=tab 1 diakses 6 Mei 2020.

Bible Work 6. 